\title{
The Meaning of Tax for Gen-Z A Study on Non-Economic Faculty Students at Ganesha University of Education
}

\author{
Nyoman Ari Surya Dharmawan ${ }^{1, *}$ I Gede Putu Banu Astawa ${ }^{1}$ Krisna Chiva ${ }^{1}$
}

\author{
${ }^{1}$ Departement of Economic and Accounting ,Universitas Pendidikan Ganesha, Singaraja, Bali, Indonesia \\ *Corresponding author. Email: arisuryadharmawan@undiksha.ac.id
}

\begin{abstract}
The purpose of this study is to examine the meaning of tax for the "Z" generation represented by students, especially final year students at the non-economic faculty of Ganesha Education University. Investigating the significance of this tax is unquestionably critical for increasing tax awareness. This is because a high degree of tax awareness is naturally associated with a high level of compliance. The outcomes of this study indicate that the context of taxes fosters more negative opinions than positive ones, resulting in the formation of a character that is still somewhat apathetic and lacking trust in the benefits of taxes for the "Z" generation.
\end{abstract}

Keywords: Tax Awareness, Tax Compliance and Generation "Z".

\section{INTRODUCTION}

State revenues from the taxation sector will undoubtedly be critical to a country's progress and the wellbeing of its citizens. Tax revenues are becoming increasingly vital in the current circumstances, amidst the health crisis and recession that has afflicted the postpandemic world, because government help or stimulus to the public is funded by tax revenues. Given the substantial income generated by the tax sector, taxpayers' (WP) understanding of the importance of paying taxes is unquestionably critical.

Taxpayer awareness is poor in Indonesia, as indicated by the fact that the country's tax deficit has increased to 8.5 percent, up from 8.08 percent in 2018 [1]. According to the Indonesian finance minister, "although the tax gap is typically around 3.6 percent for other nations, based by Indonesia's ability to collect taxes, there is actually a potential tax gap that we must bridge by close to $5 \%$ of GDP." This tax gap exists as a result of the discrepancy between the amount of tax required by the taxpayer at a particular point in time (e.g. tax year) and the amount of tax paid to the state treasury [2].

The solution to narrowing the tax gap is to develop an early understanding of taxation. The purpose of fostering this understanding is, of course, to instill in the Taxpayer an awareness of his commitment to pay taxes honestly and without pressure. Increased tax awareness can result in increased taxpayer compliance with their tax duties. Today's tax collecting system is a self-assessment system, which provides taxpayers with the confidence to calculate, declare, and deposit their tax debts contained in the Tax Return (SPT). As a result, comprehension and knowledge of the WP are required. As a result, it is critical to promote tax awareness, even more so in a country with a big population of working age, such as Indonesia.

Indonesia is one of the world's countries with a sizable population of productive age, with a total population of 74.93 million people [3]. This country began receiving a demographic bonus in 2015, when the population of productive age (15-64 years) exceeded the population of unproductive age (under 15 years and over 64 years) [4]. Naturally, the population in this productive age is dominated by those born between 1995 and 2010, and they are designated by the gene name (generation) "Z." (Bencsik, Csikos, and Juhez, 2016). According to data, only 42 million people with an NPWP are registered in the tax administration system, despite the fact that Indonesia has a population of roughly 260 million people and a workforce of 131 million people. Additionally, when examined more closely, just 17.6 million of the 42 million registered taxpayers are required to submit a notification letter (SPT) to the authorities. Meanwhile, 
just 70.4 percent of taxpayers (WP) who are obligated to submit SPT do so.

Given this situation, tax knowledge is critical for the next generation [5], particularly for Gen "Z," which will rule the economy in the future. Thus, it is reasonable to expect that Gen $\mathrm{Z}$ will be prepared to assist in moving the wheels of the national economy in the future, and they are, of course, a possible field of future tax payers [6]. Additionally, Arisandy (2017) and Tene et al. (2017) discovered that taxpayer awareness of tax compliance can be increased by knowledge and comprehension of taxation. As a result, it becomes extremely intriguing to investigate Gen "Z's" comprehension and knowledge of taxation in order to develop an awareness of tax compliance.

\section{LITERATURE REVIEW}

Tax knowledge and understanding are inextricably linked. Numerous sources have defined tax, including Law No. 16 of 2009 and other experts. According to article 1 paragraph 1 of Law No. 16 of 2009 [7], tax has the following definitions:

"mandatory contributions to the state owed by individuals or entities that are coercive in nature based on the law, without receiving direct reciprocity and are used for the needs of the state for the greatest prosperity of the people."

According to Prof.DR. H. Rochmat Soemitro SH [8] tax is:

"People's contributions to the State Treasury are based on the law (which can be enforced) without receiving reciprocal services (counter performance) that can be directly shown and which are used to pay general expenses. The definition was then corrected which reads as follows: Tax is the transfer of wealth from the people to the State Treasury to finance routine expenditures and the surplus is used for public saving which is the main source for financing public investment."

\section{According to Prof Dr. P.J.A. Andriani [9] tax is}

"contributions to the state (which can be enforced) owed by those who are obliged to pay them according to regulations, without getting performance back that can be directly appointed, and whose purpose is to finance general expenditures related to the tasks of the State which administers the government."

\section{According to Mardiasmo [10] Tax is:}

"Contributions paid by the people to the state that are included in the state treasury that implement the law and its implementation can be coerced without any remuneration. The contribution is used by the state to make payments in the public interest."
Similarly, the present tax collecting system is a selfassessment system, which provides taxpayers with the confidence to calculate, declare, and deposit their tax debts as specified in the Tax Return (SPT). According to several of the definitions above, taxes are understood to play a critical role in the advancement of the state and its benefits to society, including public services, social protection, order and safety, health, national defence, tourism, housing and public facilities, environmental protection, economy, security, and religion [11] . As a result, enough knowledge and understanding are required to foster awareness and achieve a high level of compliance.

Building awareness undoubtedly involves knowledge and comprehension, which means that researching comprehension is not an easy task; it will, of course, demand a method. Husserl's transcendental phenomenological technique can undoubtedly be used to attempt to explain or expose the meaning of concepts or experience phenomena based on the occurrence of awareness. According to Geertz [12], in order to comprehend meaning, a researcher must engage in a process known as deep painting (thick description), which is essentially the same as interpretation. Phenomenology is capable of convincingly revealing objects, even when the object is a cognitive one, as well as movements or speech. Phenomenology is capable of doing so as a result of everything someone does. Constantly mentally engaged. A critical aspect of phenomenology is:

"First, that in every human experience there is something essential, important, and meaningful. Second, one's experience must be understood in its context. Husserl epoche"

Furthermore, noted that using phenomenology as a research approach allows for the description of multiple people's life experiences with a concept or phenomenon; so, this research would employ phenomenology in examining a meaning.

\section{METHOD}

This research employs a descriptive qualitative methodology. Qualitative descriptive research is conducted by elaborating on previously identified problems or concerns, or in other words, by attempting to unearth previously unknown information [13]. The phenomenon that will be exposed in this study is related to knowledge from the perspective of Gen "z." As resource individuals or informants, final year students from Ganesha University of Education represent Gen "Z." The reason for using final-year students is that they will almost certainly work after graduation, and thus are considered future taxpayers.

The data analysis model used in this study is the Miles and Huberman model [14]. According to his research, 
qualitative data analysis activities should be interactive and continuous in nature in order to saturate the data. Data analysis is the process of arranging and classifying data into patterns, categories, and basic descriptive units in order to identify themes and locations based on proposed hypothetical data [15]. According to Miles and Huberman's analytical paradigm, the following procedures were taken to analyze the data: (1) Data collecting; (2) Data reduction; and (3). Presentation of data.

\section{RESULTS \& DISCUSSION}

Awareness, without a doubt, demands knowledge and comprehension on the part of each individual viewing a situation. As a result, we need to investigate the following: (1) tax expertise and (2). Taxation knowledge. Once that is accomplished, we will know how much awareness there is.

\subsection{Tax Awareness Among Generation " $\mathrm{Z}$ "}

Tax knowledge, of course, cannot be divorced from the meaning inherent in its comprehension. According to Article 1 paragraph 1 of Law No. 16 of 2009, tax means the following:

"mandatory contributions to the state owed by individuals or entities that are coercive in nature based on the law, without receiving direct reciprocity and are used for the needs of the state for the greatest prosperity of the people."

On the basis of this definition, it can be concluded that all persons, including individuals and groups or institutions, owe a duty to their country. Naturally, this contribution is coercive and legal in nature, implying that it adheres to a formal and explicit rule of law. This contribution is monetary in nature and there is no direct exchange.

The results of interviews with Gen "Z" students at Ganesha University of Education revealed that the tax was frequently connected with "tribute," as the goddess expressed (not her real name). Dewi stated that "taxes are $y$ "tributes," analogous to the kingdom's era. Payment of tribute to the state in the form of money. The majority of respondents also did not realize that their contribution was legally protected and did not result in direct reciprocity, as brother Komang said. According to Komang, "the tax is collected arbitrarily and we receive nothing." As a result, the majority of the interview's findings indicate that Gen-Z "Knowledge "'s of taxation is still very limited or nonexistent.

\subsection{Tax Understanding on Generation ' $Z$ "}

Taxes are primarily utilized to fund the state's demands in order to maximize the prosperity of the populace. Naturally, the progress of public services, social protection, order and safety, health, national defence, tourism, housing and public facilities, environmental protection, economy, and religion all connect with the prosperity of the people. Additionally, taxes account for $70 \%$ of state revenue.

According to the results of interviews with Gen "Z" students at Ganesha University of Education, the majority of them acknowledged the value of taxes for the welfare of the people, but many voiced doubts or scepticisms regarding the appropriation process, as demonstrated by Luh Ayu and Gede Adi. Luh Ayu noted that while taxes are undoubtedly used for the benefit of the people, a substantial amount of money is tainted in the process. Similarly, as Gede Adi's brother observed, "tax revenue is intended for the people, yet the people never benefit from it."

\subsection{Tax Awareness and Understanding in Generation " $Z$ "}

Indonesia's current tax collection system is a selfassessment system. a collection system that provides taxpayers with the confidence to calculate, disclose, and deposit their tax debts contained in their tax return (SPT). According to the results of interviews with Gen " $Z$ " students at Ganesha University of Education, the majority of them claimed that they were unaware of the tax collection process, including how it was computed and reported. As a result, it may be argued that Gen "Z" has a low degree of awareness, which translates into low compliance.

\section{CONCLUSION}

In general, people, who are heavily represented by the millennial and generation $\mathrm{Z}$ generations, remain apathetic and have little faith in the existence of taxes. This is because taxes are connected with or equated with "tributes," are costly, frequently difficult to pay, and are complicated to calculate and report. Additionally, while the facts in the area are well-known, there is a plethora of hoax news circulating in cyberspace, individuals who are not computer savvy will undoubtedly be impacted. As a result, if we consider the situation outlined above, it is not incorrect to refer to this generation as a "tax blind generation."

\section{REFERENCES}

[1] "Begini Perbandingan Tax Gap Indonesia dengan Negara Maju.” https://www.liputan6.com/bisnis/read/4593159/beg ini-perbandingan-tax-gap-indonesia-dengannegara-maju.

[2] "MEMAHAMI TAX GAP." https://bppk.kemenkeu.go.id/content/artikel/balaidiklat-keuangan-denpasar-memahami-tax-gap2020-01-09-6bfb976f/\#: :text=Tax Gap diartikan sebagai perbedaan,jumlah pajak yang sebenarnya 
dibayar.\&text=Pentingnya Tax Gap ini dapat,strategi pada Direktorat Jenderal Pajak.

[3] "keuntungan demografi indonesia." https://www.bappenas.go.id/id/.

[4] World Bank, "Development Report," Washington DC, USA, 2015.

[5] A. Bencsik, G. Csikos, and T. Juhaz, "Y and Z Generations at Workplaces," J. Compet., pp. 90106, 2016.

[6] "Edukasi Pajak untuk Generasi Z dan Milenial." https://pajak.go.id/id/artikel/edukasi-pajak-untukgenerasi-z-dan-milenial.

[7] PENETAPAN PERATURAN PEMERINTAH PENGGANTI UNDANG-UNDANG NOMOR 5 TAHUN 2008 TENTANG PERUBAHAN KEEMPAT ATAS UNDANGUNDANG NOMOR 6 TAHUN 1983 TENTANG KETENTUAN UMUM DAN TATA CARA PERPAJAKAN MENJADI UNDANG-UNDANG. 2009.

[8] Soemitro, Teori Perpajakan dan Kasus. Bandung: Eresco, 2007.

[9] Adriani, Teori Perpajakan. Jakarta: Salemba Empat, 2014.

[10] Mardiasmo, Perpajakan. Yogyakarta: Andi, 2016.

[11] M. Jaya, "Realita Kesadaran Pajak di Kalangan Generasi Muda (Mahasiswa) Yogyakarta dan Surabaya," J. Ilm. Akunt., vol. 4, no. 2, pp. 161-183, 2019.

[12] Geertz and Clifford, Tafsir Kebudayaan. Yogyakarta: Kanisius Press, 1992.

[13] M. . Miles and H. A.M, Analisis Data Kualitatif. Jakarta: Universitas Indonesia, 1984.

[14] Miles, B. Mathew, and M. Huberman, Analisis Data Kualitatif Buku Sumber Tentang Metode-metode Baru. Jakarta: UIP, 1992.

[15] Moelong and Lexy, Metodologi Penelitian Kualitatif. Bandung: PT Remaja Rosdakarya, 2005. 